\title{
Conservation evaluation for birds of Brachylaena woodland and mixed dry forest in north-east Tanzania
}

NORBERT J. CORDEIRO and MWANGI GITHIRU

\begin{abstract}
Summary
Three forest and woodland sites were surveyed in the lowlands of the East Usambara mountains, Tanzania, from August to October, 1996. Bombo East I and II Proposed Forest Reserves (PFR) and Bombo West FR were previously unknown biologically. Our fieldwork revealed several records of conservation interest. Four species of global conservation concern (Amani Sunbird Anthreptes pallidigaster, Southern Banded Snake Eagle Circaetus fasciolatus, Fischer's Turaco Tauraco fischeri and Plain-backed Sunbird Anthreptes reichenowi) were recorded, with a further seven species of regional concern. These sites were not as rich in bird species as other East Usambara lowland forests. Bombo East I PFR had the highest richness, which included the presence of three montane species that were most likely cold-season visitors. The Endangered Sokoke Scops Owl Otus ireneae, otherwise known from similar woodland habitat in Kenya as well as lowland forest in the East Usambaras, was apparently absent at these sites. It is also clear from our survey that at least four threatened mammals and one possibly endemic snake inhabit the Brachylaena woodlands and mixed dry forest. Thus, our results indicate that the previously unexplored Brachylaena woodlands and mixed dry forest in north-east Tanzania are an additional habitat to some fauna of threatened status and do, therefore, merit conservation attention. The Brachylaena tree is highly favoured for charcoal production and the enormous demand for this product is increasing the degradation of these woodland patches. Larger tracts of unprotected Brachylaena woodland should receive immediate conservation attention.
\end{abstract}

\section{Introduction}

The East Usambara mountains are of great conservation significance since they comprise both Eastern Arc and lowland "Coastal" forest types (Burgess et al. 1998, Burgess in press). The Eastern Arc forests occur above $800 \mathrm{~m}$ and are moist, montane ecosystems whereas the lowland coastal forests which occur below this altitude are more seasonally influenced. Both forest types are biologically rich and together house many globally threatened and endemic animal and plant species (e.g. Lovett and Wasser 1993, Stattersfield et al. 1998, Burgess et al. 1998). With respect to birds, more attention has focused on the submontane elements (e.g. Sclater and Moreau 1932-1933, Stuart 1983, 1989) and only recently has there been greater coverage of the lowland avifauna (Evans and Anderson 1993, Evans et al. 1994, CTRP 1994, Evans 1997a). These latter studies added three globally threatened species not previously known from the Usambaras (Sokoke Scops 
Owl Otus ireneae, East Coast Akalat Sheppardia gunningi, Swynnerton's Robin Swynnertonia swynnertoni), as well as several new vertebrate and invertebrate taxa.

Even though new populations of several threatened mammal, bird and herpetile species have been discovered in these lowland forests (see Burgess et al. 1998, Burgess et al. in press, Mlingwa et al. in press, Broadley and Howell in press), many vestigial forest patches remain unexplored and are currently unprotected (Sheil 1992, Burgess et al. 1993, Burgess in press). Additionally, prior to our investigations, the adjacent Brachylaena-dominated habitat had not received any biological or significant conservation attention despite its potential as an important refuge for endemic Eastern Arc and Coastal Forest biota. Habitat degradation continues to threaten the vestigial forest patches and, especially, the Brachylaena woodland, which is cleared for subsistence farming and charcoal burning by an expanding human population.

Although our focus was primarily on birds and the threats to their habitats in three unexplored and very recently mapped lowland forest and Brachylaenadominated woodland patches, other biota and aspects of human utilization also received attention (N.J.C., M.G., unpubl.). Since a short summary article was written on the most important avifaunal results from this work (Cordeiro and Githiru 1998), here we will focus more on: (1) describing the assemblages of these sites and compare them with adjacent lowland forests; (2) providing annotated accounts on species of conservation concern at the global and regional levels; and (3) discussing the conservation priorities of the areas visited and the Brachylaena woodland habitat in north-east Tanzania. A fourth forest reserve visited during this period, Mgambo Proposed Forest Reserve (PFR), largely comprises different habitat types in comparison with the other three discussed here. Due to these habitat differences, discussion of the avifauna of Mgambo PFR would fall beyond the scope of this paper and therefore reported elsewhere (Cordeiro and Githiru in press).

\section{Physical geography}

Forest cover, which comprises a total of about 25,000 ha in the highlands and lowlands of the East Usambaras (Hamilton and Bensted-Smith 1989, CTRP 1994), has been fragmented into a network of patches due to human activities over the past few thousands of years (Schmidt 1989, Newmark 1993), especially so since the late 1800 s due to the establishment of colonial estates, followed by sisal and tea plantation and shifting cultivation (M.I.L. Katigula and S. Johansson in litt. 1997, see also Hamilton and Bensted-Smith 1989). More details on the vegetation, climate and physical and social geography of the East Usambaras can be found elsewhere (Moreau 1935, Hamilton and Bensted-Smith 1989, AFIMP 1987, Lovett and Pócs 1993).

Sites that were surveyed are briefly described below (see Figure 1) with details of the general relief, dominant vegetation, canopy height and surrounding villages. The soil at all sites and in much of the lowlands is a red-brown sandy-clay type, classified as rhodic ferrasol (Hamilton and Bensted-Smith 1989). To determine the common plants at each site, specimens were processed and sub- 


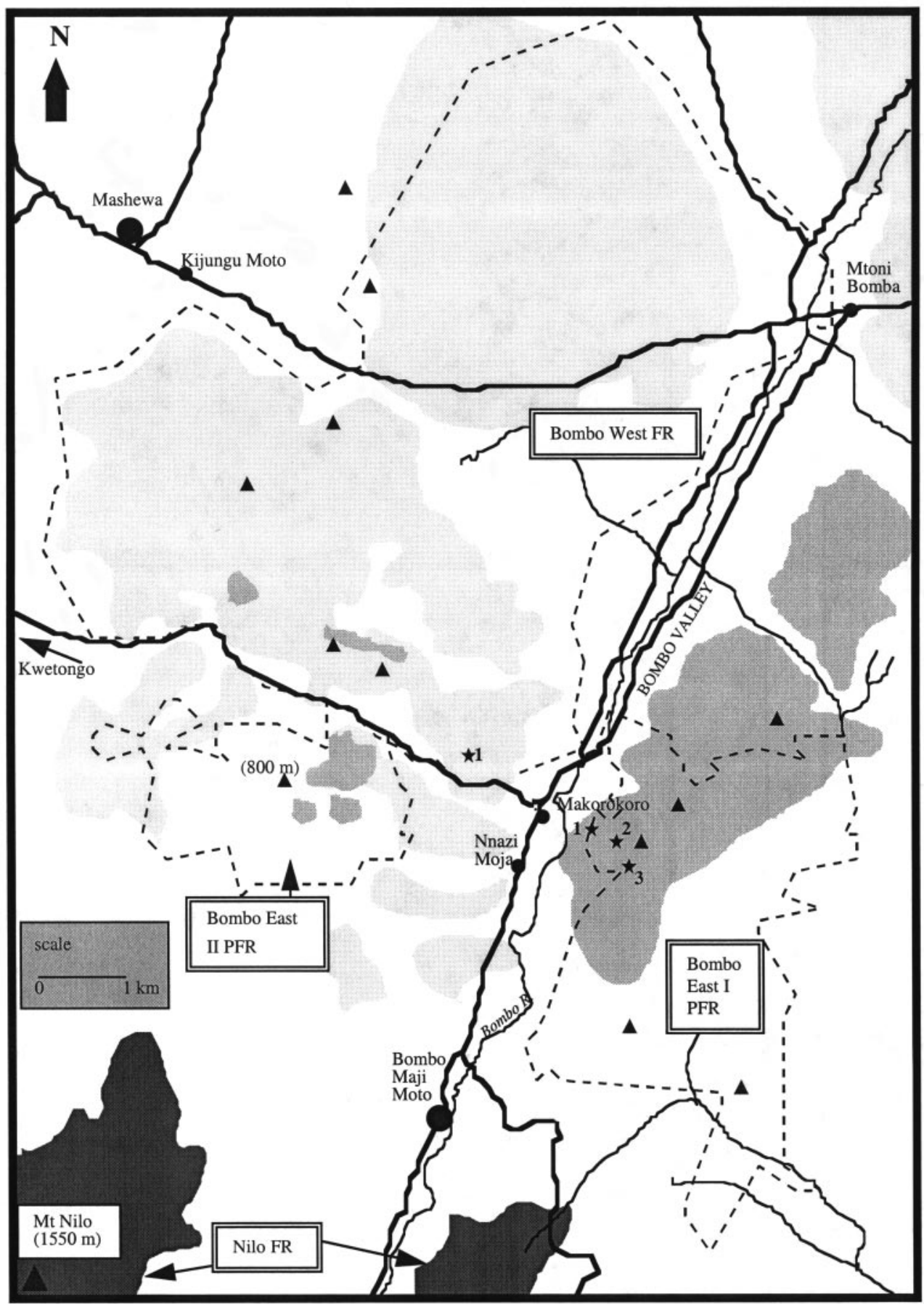

Key:

$\square$ Brachylaena woodland $\square$ mixed dry forest $\square$ submontane/montane forest motor track $\Delta$ hill (close to or just above $600 \mathrm{~m}$ ) $\quad \star$ mist-net sites

Figure 1. Map showing mist-net sites and locations of Bombo East I and II Proposed Forest Reserves, Bombo West Forest Reserve and adjacent Nilo Forest Reserve. Three different habitat types are shown; Acacia woodland, wooded grassland and cultivation occur in the surrounding areas. The extent of the Brachylaena woodland and mixed dry forest shown on this map is based on our observations and the main reference map (SMD 1991). Aerial photographs would have made this map more accurate. 
sequently identified at the East African Herbarium, Nairobi. Although most plants were identified some could only be placed to genus.

Mean minimum and maximum temperatures for this study period ranged from 17.9 to $27.9^{\circ} \mathrm{C}$ (data from Kilangangua Forest Station, at head of Bombo Valley). Rainfall is estimated at about $750 \mathrm{~mm}$ per year for this area (Lovett and Pócs 1993). Although we did not obtain data on rainfall, we made note of small light showers which fell in late September and became more frequent and lasted longer by October. It appeared that more rain fell in the Bombo East I PFR hills, than on much of the valley floor. Mist persisted for short periods on the uppermost parts of these forested hills during fairly cool mornings and evenings.

\section{Description of Bombo East I and II Proposed Forest Reserves}

Both these hill-top forests lie in the Bombo Valley; Bombo East I PFR ( $04^{\circ} 49^{\prime}$ S, $38^{\circ} 42^{\prime} \mathrm{E}$ ) which rises from about $250-600 \mathrm{~m}$, is almost equally split between Muheza and Korogwe Districts, Tanga Region. Bombo East II PFR ( $04^{\circ} 49^{\prime} \mathrm{S}$, $38^{\circ} 4 \mathrm{o}^{\prime} \mathrm{E}$ ) which has an elevational range from $c .450$ to $850 \mathrm{~m}$, is located in Korogwe District (Figure 1). Bombo East I PFR, the larger of two, has an area of 1,120 ha. Bombo East II PFR is on a hill called Mlima Mwarabu and comprises an area of 470 ha (Johansson and Sandy 1996). Following the mapping surveys of 1996 by the East Usambara Catchment Forest Project (hereafter EUCFP, R. Sandy verbally 1996), demarcation of the boundaries took place at the time of this study. The vegetation of Bombo East I PFR includes a mosaic of Brachylaena woodland, mixed Brachylaena and lowland forest species, and dry Acacia woodland bordering the main forest blocks. The semi-deciduous mixed Brachylaena woodland and lowland forest habitat, being unique in the East Usambaras, is here termed mixed dry forest after Clarke et al. (in press). This habitat, which persists on the hills of both PFRs as well as two small hills in the southern extreme of Bombo West FR, probably survives as such by drawing more moisture from the wetter and adjacent East Usambara mountains. Average canopy height varies from 10 to $25 \mathrm{~m}$ with emergents up to $40 \mathrm{~m}$. These characteristics along with a more distinctive stratification, differentiated this habitat from the more open, shorter canopy and less diverse Brachylaena vegetational community.

Several tree species, with a canopy height of about $10-25 \mathrm{~m}$, dominate the mixed dry forest on the hill making it diverse in terms of species composition and vegetation structure. Trees and shrubs include Combretum spp., Brachylaena huillensis, Scorodophloeus fischeri, Strychnos henningsi and up to 40-m-tall Sterculia appendiculata on the large valley slopes. Combretum holstii, Croton dichogamus, Cordia spp., Uvaria acuminata and saplings of some of the above species occurred less commonly within this community. Average canopy tree $\mathrm{dbh}$ in the Brachylaena-dominated area was $19.1 \mathrm{~cm}$ (range $=6-30.9 \mathrm{~cm}, n=12$ ) and mean canopy tree $\mathrm{dbh}$ in the mixed dry forest was 15.2 (range $=10.2-34.1 \mathrm{~cm}, n=16)$. Acacia wooded-grassland and cultivation surrounded this vegetation type.

Bombo East II PFR was dominated by a forest mosaic similar to Bombo East I PFR and was surrounded either by cultivation, Brachylaena woodland or Acacia wooded-grassland. Apart from the rice-cultivated Bombo River at the foot of the Bombo East I hill, there was little evidence of streams in either of the reserves despite indications on the reference map (SMD 1991). Of the villages that sur- 
round these reserves (Figure 1), Nnazi Moja, Makorokoro and Bombo Maji Moto appear to benefit the most through the use of a variety of resources. General interviews with residents from each village, village chairpeople, forestry personnel and personal observations indicate that dry wood is collected for firewood and Brachylaena trees are quite often sought by charcoal makers and wood carvers. Grazing in the grassy woodlands also occurs.

\section{Description of Bombo West Forest Reserve}

This reserve $\left(04^{\circ} 47^{\prime} \mathrm{S}, 38^{\circ} 4 \mathrm{o}^{\prime} \mathrm{E}\right)$ located in the Bombo Valley, Korogwe District, comprises 3,564 ha (Johansson and Sandy 1996) and has an elevational range from about 400 to $700 \mathrm{~m}$ (Figure 1 ). Bombo West FR is largely dominated by Brachylaena huillensis (mean $\mathrm{dbh}=27.9 \mathrm{~cm}$, range $=16.3-50.5 \mathrm{~cm}, n=24$ ) woodland (Figure 1, Lovett and Pócs 1993), although several other trees and shrubs occur commonly such as Scorodophloeus fischeri, Uvaria spp., Combretum sp., Croton spp., Cynometra spp., Grewia spp., Euphorbia spp., Adenium obesum, Teclea trichocarpa, Strychnos usambarensis and S. henningsi. This woodland type is now known as Brachylaena huillensis dry forest (Clarke et al. in press), but we choose to refer to it here as woodland habitat to distinguish it from mixed dry forest that envelopes the hills in these reserves. Patches of Acacia-Commiphora-Sterculia woodland occur within and adjacent to the Brachylaena habitat where cultivation is not present. Two grasses, Sporobolus and Digitaria spp., inhabit both woodland types. The canopy height ranges from 6 to $15 \mathrm{~m}$ with a few emergents reaching about $20 \mathrm{~m}$. The boundaries were marked again recently and a small portion on the southern side is now connected with the newly established Bombo East II PFR (Figure 1). Based on general interviews with residents and leaders of most of the surrounding villages, and personal observations, Nnazi Moja, Makorokoro, Kwetongo, Mashewa and Kijungu Moto (Figure 1) may have a fairly large investment in Bombo West FR. All the uses mentioned above for Bombo East I PFR are in common with Bombo West FR; however, the western and southern parts of this reserve are closest to these thriving villages and therefore are more devoid of dry wood. Many villagers were observed collecting and transporting fuelwood to these villages, particularly to Mashewa and Kijungu Moto.

\section{Brachylaena uses}

Brachylaena huillensis is an evergreen tree that grows extremely slowly, usually attaining heights of 6-18 m. It occurs in upland semi-deciduous forests where it is often common, and is also abundant in dry lowland habitats. Past and present uses of this tree species include timber production, wood carving and fuelwood for both charcoal burning and firewood (Beentje 1994). It has medicinal value in that the root has been used in the treatment of schistosomiasis (Ruffo et al. 1989). The tree is in great demand because it gives very long-burning, smokeless fuelwood and its wood is highly favoured for carving. Principally due to its importance in wood carving, but more so for the charcoal industry, it has been excessively harvested from almost pure stands in unprotected tracts north of the East Usambara mountains (see Cordeiro and Githiru 1998). Furthermore, the tree has been selectively removed from natural mixed forests in coastal kayas of 
Table 1. Mist-net effort, altitude and habitats of each mist-net site in Bombo East I Proposed Forest Reserve (PFR) and Bombo West FR. Mist-net effort is indicated in net-metre-hours (product of total net transect multiplied by time nets were operated)

\begin{tabular}{lcccc}
\hline & \multicolumn{3}{c}{ Bombo East I PFR } & Bombo West FR \\
\hline Sites & $1 \mathrm{a}, \mathrm{Ib}$ & $2 \mathrm{a}, \mathrm{b}$ & $3 \mathrm{a}, \mathrm{b}$ & $1 \mathrm{a}, \mathrm{b}$ \\
Habitats & $\mathrm{MFe}$ & $\mathrm{MFv}$ & $\mathrm{MF}$ & $\mathrm{B}$ \\
Altitude (m) & 400 & 500 & 400 & 500 \\
Diurnal total & 3696 & 3024 & 3640 & 7090 \\
Total diurnal effort & & 10360 & & 7090 \\
& & 4032 & 9600 \\
Nocturnal total & 5376 & 2688 & & 9600 \\
Total nocturnal effort & & 12096 & & \\
\hline
\end{tabular}

Habitat abbreviations: MF, mixed dry forest; Mfe, edge of mixed dry forest dominated by

Brachylaena; Mfv, valley slope with mixed dry forest; B, Brachylaena woodland.

Kenya (Robertson 1987) and from Mt Kasigau in Kenya (M.G. pers. obs. 1998). In the Arabuko Sokoke Forest, the Cynometra-Manilkara-Brachylaena woodland has been severely modified by removal of Brachylaena, to the extent that it is now usually referred to as Cynometra woodland (Virani 1994).

\section{Methods}

Methods were designed to locate as many species as possible in the time available, especially targeting those species of conservation concern (see Cordeiro 1998). Audio-visual observations, serving the purpose of locating as many species as possible in a variety of habitats and elevations, were conducted daily. As well as using pre-recorded calls and playback to attract birds, dawn choruses were recorded at each site to document species that may have gone unnoticed through the other techniques (Svendsen et al. 1995).

Mist-netting of birds in a variety of habitats (see Table 1) during the day and night was also employed to capture the more elusive understorey birds. Birds were ringed with East African Ringing Scheme rings and standard biometric measurements, moult and brood patch scores were recorded. Diurnal mistnetting efforts amounted to 17,450 net-metre-hours (hereafter $\mathrm{nmh}$ ) and nocturnal, 21,696 nmh totals for all sites combined (Table 1). Greater netting effort was focused on Bombo East I PFR due to the unique vegetation types. Netting was not conducted in Bombo East II PFR. The use of mist-nets is a good technique to locate elusive understorey dwellers that may otherwise be unnoticed (e.g. Karr 1981), but is biased to an extent that makes it of poor value for documenting community parameters (e.g. Remsen and Good 1996). Bombo East I PFR and Bombo West FR/Bombo East II PFR were surveyed from 10-30 September and 30 September to 10 October, respectively. Nomenclature and systematics follow Zimmerman et al. (1996).

\section{Results}

Mist-netting

Twenty-eight species (147 individuals) were captured in the two forest reserves. Twenty-five (121 individuals) and 14 (26 individuals) species were captured at 
Table 2. Number of species and individuals captured in mist-nets in each habitat (see Table 1 for key to abbreviations) from the two forest reserves. Recapture data are not included

\begin{tabular}{|c|c|c|c|c|c|}
\hline \multirow[t]{2}{*}{ Species } & \multicolumn{3}{|c|}{ Bombo East } & \multirow{2}{*}{$\frac{\text { Bombo West }}{\text { B }}$} & \multirow[t]{2}{*}{ Total } \\
\hline & MFe & MFv & MF & & \\
\hline African Goshawk Accipiter tachiro & - & 1 & 1 & - & 2 \\
\hline Tambourine Dove Turtur tympanistria & - & - & 1 & - & 1 \\
\hline Emerald-spotted Wood Dove T. chalcospilos & - & - & - & 1 & 1 \\
\hline Yellowbill Ceuthmochares aereus & - & - & 2 & - & 2 \\
\hline Narina Trogon Apaloderma narina & - & 1 & - & 1 & 2 \\
\hline Fischer's Greenbul Phyllastrephus fischeri & 2 & 8 & 9 & 1 & 20 \\
\hline Northern Brownbul P. strepitans & 2 & - & - & - & 2 \\
\hline Terrestrial Brownbul $P$. terrestris & 1 & 3 & 3 & - & 7 \\
\hline Tiny Greenbul $P$. debilis & 1 & 2 & 4 & - & 7 \\
\hline Yellow-bellied Greenbul Chlorocichla flaviventris & 4 & - & 1 & 5 & 10 \\
\hline Eastern Nicator Nicator gularis & 4 & - & 1 & 3 & 8 \\
\hline White-starred Forest Robin Pogonocichla stellata & - & - & 1 & - & 1 \\
\hline Red-capped Robin-chat Cossypha natalensis & 11 & 1 & 4 & - & 16 \\
\hline White-chested Alethe Alethe fuelleborni & 1 & - & - & - & 1 \\
\hline Red-tailed Ant Thrush Neocossyphus rufus & 1 & - & - & - & 1 \\
\hline Eastern Bearded Scrub Robin Cercotrichas quadrivirgata & 6 & 1 & 2 & 5 & 14 \\
\hline Grey-backed Camaroptera Camaroptera brachyura & 4 & - & 5 & 2 & 11 \\
\hline Yellow-breasted Apalis Apalis flavida & - & - & 2 & 1 & 3 \\
\hline Blue-mantled Crested Flycatcher Trochocercus cyanomelas & 2 & 1 & 1 & - & 4 \\
\hline African Paradise Flycatcher Terpsiphone viridis & 2 & 1 & 2 & 1 & 6 \\
\hline Forest Batis Batis mixta & - & 2 & 7 & - & 9 \\
\hline Retz's Helmet-shrike Prionops retzii & - & - & - & 1 & 1 \\
\hline Grey-headed Bush-shrike Malaconotus blanchoti & - & - & - & 1 & 1 \\
\hline Tropical Boubou Laniarius aethiopicus & 1 & - & 1 & 2 & 4 \\
\hline Black-backed Puffback Dryoscopus cubla & 1 & - & - & 1 & 2 \\
\hline Plain-backed Sunbird Anthreptes reichenowi & - & 1 & 1 & 1 & 3 \\
\hline Collared Sunbird A. collaris & - & - & 1 & - & 1 \\
\hline Peter's Twinspot Hypargos niveoguttatus & 2 & - & 5 & - & 7 \\
\hline Totals for each reserve & & & 121 & 26 & \\
\hline
\end{tabular}

Bombo East I PFR and Bombo West FR, respectively (Table 2). The most abundant species in the netted sample included Fischer's Phyllastrephus fischeri and Yellow-bellied Greenbuls Chlorocichla flaviventris, Red-capped Robin-chat Cossypha natalensis, Eastern Bearded Scrub Robin Cercotrichas quadrivirgata, Greybacked Camaroptera Camaroptera brachyura and Forest Batis Batis mixta (Table 2). Although several bats were caught, no nocturnal birds were captured.

\section{Species check-list}

Data on the number of species at Bombo East I PFR and Bombo West FR are presented in Table 3. All species recorded in Bombo East II PFR were also noted in Bombo West FR and, since the two are connected by a narrow corridor, it would seem that they share a similar avifauna. The mixed dry forest in Bombo East II PFR was not sufficiently surveyed as more effort was concentrated in the Brachylaena woodland. One hundred and eighty four taxa from all sites were recorded, but only those from the forest and Brachylaena woodland are listed in 
Table 3. Bombo East I PFR had the highest species richness with 143 species $(65$ mixed dry forest and Brachylaena species, 78 Acacia woodland and cultivation species) whereas 122 species (54 mixed dry forest and Brachylaena species, 69 Acacia woodland and cultivation species) were recorded in Bombo West FR (Table 3; N.J.C. and M.G., unpubl.). For further details on several other species see Cordeiro and Githiru (in press).

\section{Species of conservation concern}

Collar et al. (1994) identify all globally threatened and near-threatened birds, using the most recent IUCN categories of threat (Mace and Stuart 1994). Categories of threat used within this text follow the global directory of Collar et al. (1994) and the regional directory of Bennun and Njoroge (1996). We also discuss restricted-range taxa to highlight other species of potential conservation concern in these habitats. Restricted-range species have a global range of $50,000 \mathrm{~km}^{2}$ or less (Stattersfield et al. 1998). We distinguish globally and regionally threatened species below.

Banded Snake Eagle Circaetus cinerascens

Regionally Vulnerable

Zimmerman et al. (1996) state that this raptor is rare in northern Tanzania. We observed both Banded Circaetus cinerascens and Southern Banded Snake Eagle C. fasciolatus in the same habitat just outside Bombo East I PFR, the former flying above the latter's nest on 13 September. This is highly unusual as the two closely related species are considered allopatric through much of their range (Britton 1980). Additionally, this record is the first of this localized species from the East African coastal region (Britton 1980, Zimmerman et al. 1996). We do not know whether this eagle is resident in mixed dry forest or Brachylaena woodland.

Southern Banded Snake Eagle Circaetus fasciolatus Globally Near-Threatened

The Southern Banded Snake Eagle has a localized distribution in coastal forest from Somalia to South Africa (Collar et al. 1994), with inland populations occurring in the semi-evergreen forests of the Kilombero/Kibashira swamps, and several Eastern Arc mountains, Tanzania. It is commonly recorded in the East Usambaras (Moreau 1935, Collar and Stuart 1985, Tye 1993, CTRP 1994).

Only one old nest, possibly of this raptor, was located in the fork of a Sterculia appendiculata tree. The breeding pair of eagles we observed had a nest in a c. 18 $\mathrm{m}$ high Combretum tree about $20 \mathrm{~m}$ outside Bombo East I PFR, at $400 \mathrm{~m}$ asl. Repetitive calling from this pair in the early morning and evening hours led us to locate this nest. The nest was about $40-50 \mathrm{~cm}$ in diameter and constructed at c. $14 \mathrm{~m}$ above the ground in the fork of the tree where the branches spread outward with much green foliage. The sex of the sitting individual was not determined. We did not observe a change in incubating individuals but periodically noted one individual flying over the nest. It appeared that young were present on 11 October. The breeding record in the mixed dry forest, together with records of its occurrence in other inland semi-evergreen forests, is of considerable conservation interest as it appears that the breeding range of this near-threatened raptor may not be strictly confined to coastal forest. 
Table 3. List of all species recorded in or near each study site in Brachylaena woodland or mixed dry forest. Birds recorded from the mixed dry forest and present in several lowland forests in the East Usambaras, but not recorded from Brachylaena woodland in Bombo West FR, are denoted with a + . Species that are chiefly montane dwellers are marked with $a *$. An $x$ indicates that the taxon may forage in, but not necessarily reside in this habitat. Some species (denoted by §) that were mainly recorded in Brachylaena woodland or mixed dry forest may also occur in the adjacent Acacia woodlands. Altitudes for certain birds are given as appropriate

\begin{tabular}{|c|c|c|c|}
\hline Species & Habitat & Bombo East & Bombo West \\
\hline Bat Hawk Macheiramphus alcinus & $t$ & & $x$ \\
\hline Southern Banded Snake Eagle Circaetus fasciolatus & & $x$ & $(\mathrm{x})$ \\
\hline African Harrier Hawk Polyboroides typus & $\S$ & $x$ & $\mathrm{x}$ \\
\hline African Goshawk Accipiter tachiro & & $\mathrm{x}$ & $x$ \\
\hline Little Sparrowhawk A. minullus & $\S$ & $x$ & $\mathrm{x}$ \\
\hline Wahlberg's Eagle Aquila wahlbergi & $\S$ & $x$ & $x$ \\
\hline African Crowned Eagle Stephanoaetus coronatus & & $\mathrm{x}$ & $x$ \\
\hline Martial Eagle Polemaetus bellicosus & $\S$ & $\mathrm{x}$ & $\mathrm{x}$ \\
\hline Sooty Falcon Falco concolor & $\S$ & & $x$ \\
\hline Crested Francolin Francolinus sephaena & + & $x$ & $x$ \\
\hline Crested Guineafowl Guttera pucherani & & $x$ & $x$ \\
\hline Tambourine Dove Turtur tympanistria & + & $x$ & $x$ \\
\hline Emerald-spotted Wood Dove T. chalcospilos & & $x$ & $x$ \\
\hline Red-eyed Dove Streptopelia semitorquata & $\S$ & $x$ & $x$ \\
\hline Fischer's Turaco Tauraco fischeri & $t$ & $x$ & $x$ \\
\hline Yellowbill Ceuthmochares aereus & & $x$ & $\mathrm{x}$ \\
\hline African Barred Owlet Glaucidium capense & & \multicolumn{2}{|c|}{$x($ below $600 \mathrm{~m}) \times($ below $600 \mathrm{~m})$} \\
\hline African Wood Owl Strix woodfordii & & $x$ & $x$ \\
\hline Mottled Swift Apus aequatorialis & $\S$ & $x$ & $(\mathrm{x})$ \\
\hline Narina Trogon Apaloderma narina & & $x$ & $x$ \\
\hline Green Wood-Hoopoe Phoeniculus purpureus & $\S$ & $x$ & $x$ \\
\hline Crowned Hornbill Tockus alboterminatus & $\S$ & $x$ & $x$ \\
\hline Trumpeter Hornbill Bycanistes bucinator & & $\mathrm{x}$ & $x$ \\
\hline Scaly-throated Honeyguide Indicator variegatus & & $\mathrm{x}$ & $\mathrm{x}$ \\
\hline Mombasa Woodpecker Campethera mombassica & & $x$ & $x$ \\
\hline Cardinal Woodpecker Dendropicos fuscescens & $\S$ & $x$ & $x$ \\
\hline African Broadbill Smithornis capensis & + & $x(400-600 \mathrm{~m})$ & \\
\hline Black Rough-wing Psalidoprocne pristoptera & $t^{*}$ & $\mathrm{x}$ & \\
\hline Fischer's Greenbul Phyllastrephus fischeri & & $\mathrm{x}$ & $\mathrm{x}$ \\
\hline Northern Brownbul P. strepitans & & $\mathrm{x}$ & $x$ \\
\hline Terrestrial Brownbul P. terrestris & & $x$ & $\mathrm{x}$ \\
\hline Tiny Greenbul P. debilis ${ }^{\mathrm{a}}$ & + & $x$ & \\
\hline Yellow-bellied Greenbul Chlorocichla flaviventris & $\S$ & $\mathrm{x}$ & $\mathrm{x}$ \\
\hline White-starred Forest Robin Pogonocichla stellata & $\dagger, *$ & $x$ & \\
\hline Red-capped Robin-chat Cossypha natalensis & & $x$ & $x$ \\
\hline Eastern Nicator Nicator gularis & & $x$ & $\mathrm{x}$ \\
\hline White-chested Alethe Alethe fuelleborni ${ }^{\mathrm{b}}$ &,$+ *$ & $x(400 \mathrm{~m})$ & \\
\hline Red-tailed Ant Thrush Neocossyphus rufus & & $\mathrm{x}$ & $\mathrm{x}$ \\
\hline Eastern Bearded Scrub Robin Cercotrichas quadrivirgata & & $\mathrm{x}$ & $\mathrm{x}$ \\
\hline Ashy Flycatcher Muscicapa caerulescens & + & $x$ & $x$ \\
\hline Grey-backed Camaroptera Camaroptera brachyura & & $x$ & $x$ \\
\hline Yellow-breasted Apalis Apalis flavida & $\S$ & $\mathrm{x}$ & $\mathrm{x}$ \\
\hline Black-headed Apalis A. melanocephala & & + & $x$ \\
\hline Little Yellow Flycatcher Erythrocercus holochlorus & & $x$ & $x$ \\
\hline Blue-mantled Crested Flycatcher Trochocercus cyanomelas & & $\mathrm{x}$ & \\
\hline African Paradise Flycatcher Terpsiphone viridis & & $x$ & $x$ \\
\hline Forest Batis Batis mixta & + & $x$ & \\
\hline Pale Batis B. soror & & & $\mathrm{x}$ \\
\hline
\end{tabular}


Table 3 cont.

\begin{tabular}{|c|c|c|c|}
\hline Species & Habitat & Bombo East & Bombo West \\
\hline Black-and-White Flycatcher Bias musicus ${ }^{\mathrm{d}}$ & & $x$ & \\
\hline Retz's Helmet-shrike Prionops retzii & $\S$ & $\mathrm{x}$ & $\mathrm{x}$ \\
\hline Chestnut-fronted Helmet-shrike P. scopifrons & $x$ & $x$ & \\
\hline Brown-crowned Tchagra Tchagra australis & & $\mathrm{x}$ & $\mathrm{x}$ \\
\hline Black-crowned Tchagra T. senegala & & $\mathrm{x}$ & $\mathrm{x}$ \\
\hline Black-fronted Bush-shrike Malaconotus multicolor & $t^{*}{ }^{*}$ & $x(400-500 \mathrm{~m})$ & \\
\hline Four-coloured Bush-shrike M. quadricolor & & $\mathrm{x}$ & $x$ \\
\hline Grey-headed Bushshrike M. blanchoti & & $\mathrm{x}$ & $\mathrm{x}$ \\
\hline Tropical Boubou Laniarius aethiopicus & & $\mathrm{x}$ & $\mathrm{x}$ \\
\hline Black-backed Puffback Dryoscopus cubla & $\S$ & $x$ & $x$ \\
\hline Black-headed Oriole Oriolus larvatus & $\S$ & $x$ & $x$ \\
\hline Eurasian Golden Oriole O. oriolus & $\S$ & $x$ & $x$ \\
\hline Waller's Starling Onychognathus walleri &,$+ *$ & $x(500 \mathrm{~m})$ & \\
\hline Black-bellied Starling Lamprotornis corruscus & & $x$ & $(\mathrm{x})$ \\
\hline Collared Sunbird Anthreptes collaris & $\S$ & $x$ & $\mathrm{x}$ \\
\hline Amani Sunbird A. pallidigaster & + & $x(400 \mathrm{~m})$ & \\
\hline Plain-backed Sunbird A. reichenowi & & $x$ (below $600 \mathrm{~m}$ ) & $\mathrm{x}($ below $600 \mathrm{~m}$ ) \\
\hline Olive Sunbird Nectarinia olivacea & t & $\mathrm{x}$ & \\
\hline Dark-backed Weaver Ploceus bicolor & + & $x$ & \\
\hline Peter's Twinspot Hypargos niveoguttatus & & $x$ & $x$ \\
\hline
\end{tabular}

${ }^{\mathrm{a}}$ ssp. rabai; ${ }^{\mathrm{b}}$ ssp. usambarae; $^{\mathrm{c}}$ ssp. ultima; ${ }^{\mathrm{d}}$ outside the PFR (see text).

Fischer's Turaco Tauraco fischeri

Globally Near-Threatened

Although quite common in the East Usambaras (Moreau 1935, Collar and Stuart 1985, Stuart 1989, Tye 1993), including the lowlands (Evans 1997a), audio-visual observations at all our study sites suggest that Fischer's Turaco occurred at lower densities than elsewhere in this range. It appears to require dense and tall woodland or forest, and was therefore only encountered in such habitat at all sites. The low densities may be apparent throughout the year or, possibly attributed to seasonal fluctuations due to availability of fruiting trees.

Mombasa Woodpecker Campethera mombassica

Restricted Range

This woodpecker is well known from the East Usambara submontane and lowland (e.g. Evans 1997a) forests. We recorded it at all three sites in fair numbers, where both Brachylaena woodland and mixed dry forest were favourite habitats. Numbers appeared greater in the mixed dry forests at all three Bombo Valley sites and the species was also regularly encountered in dense Brachylaena woodland in Bombo West FR. Of interest, however, is the lack of records from the adjacent Acacia woodlands although individuals were occasionally observed at the margins of these habitats.

White-chested Alethe Alethe fuelleborni Globally Restricted Range

Well known in the East Usambara submontane and lowland forests (Moreau 1935, Stuart 1989, Tye 1993, Evans 1997a), this thrush was netted once in the transition area between Brachylaena stands and mixed dry forest in Bombo East I PFR. 
Little Yellow Flycatcher Erythrocercus holochlorus

Regionally Vulnerable

This flycatcher is another species known from a select few sites in East Africa, including the East Usambara lowlands (e.g. Stuart 1989, Evans 1997a). It was a regular member of mixed species flocks and commonly recorded in Bombo East I PFR, especially in the mixed dry forest, but was less common in the Brachylaena woodland in Bombo West FR.

Amani Sunbird Anthreptes pallidigaster

Globally Vulnerable

In the East Usambaras, this low-density bird is known from only a few scattered records, ranging from low-altitude to submontane forest (e.g. Moreau 1935, Stuart 1989, Tye 1993, Evans 1997a, Cordeiro 1998, Seddon et al. 1999). A male was recorded only once in Bombo East I PFR in the rather dense mixed dry forest and it must therefore be scarce or overlooked here. Whether this record represents a resident or wanderer remains to be seen.

Plain-backed Sunbird Anthreptes reichenowi

Globally Near-Threatened

Frequently recorded at all three sites, having been known in the East Usambaras mainly from the lowland forests (Evans 1997a), this species regularly joined mixed-species flocks and was also observed feeding alone or in pairs. Given its presence at these sites, the population of this sunbird would therefore appear reasonably secure.

\section{Other widespread species of conservation concern}

Another six species of conservation concern at the regional level (Regionally Near-Threatened, RNt; Regionally Vulnerable, RV; Regional Responsibility, RR) were found at these sites: Bat Hawk Macheiramphus alcinus (RNt), African Crowned Eagle Stephanoaetus coronatus (RV), Martial Eagle Polemaetus bellicosus (RV), Fischer's Greenbul Phyllastrephus fischeri (RR), Chestnut-fronted Helmetshrike Prionops scopifrons (RNt) and Four-coloured Bush-shrike Malaconotus (RNt). The first four are generally widespread in the region whereas the last two are most restricted in range, both generally confined to the coastal area (Britton 1980, Zimmerman et al. 1996). Chestnut-fronted Helmet-shrike is well known from the East Usambara lowlands (e.g. Stuart 1989, Evans 1997a). We observed three to four different flocks of this species in the Brachylaena woodland of Bombo West FR; however, only one flock was encountered in Bombo East I PFR. Although known from some inland forests such as the North Pare Mountains and Chyulu Hills (Britton 1980, Cordeiro and Kiure 1995, Zimmerman et al. 1996), Four-coloured Bush-shrike is primarily a coastal forest dweller. We recorded it in mixed dry forest and Brachylaena woodland at all three sites where it was not uncommon.

\section{Montane elements}

Several montane birds are believed to move to lower altitudes during the cold season and have thus been reported from the East Usambara lowlands during 
this season (e.g. Stuart 1989, CTRP 1994, Evans 1997a). Five montane elements, Black Rough-wing Psalidoprocne pristoptera, White-starred Forest Robin Pogonocichla stellata, Black-fronted Bush-shrike Malaconotus multicolor, Waller's Starling Onychognathus walleri and White-chested Alethe were noted from the mixed dry forest in Bombo East I PFR (Table 3). If these species are not residents or wanderers, then they are most likely montane visitors in the lowlands during the cold season as has been observed elsewhere in the Eastern Arc mountain range (e.g. Burgess and Mlingwa in press). The behavioural and evolutionary significance of this downward movement in East Africa requires further study as conservation strategies may need to focus on the entire elevational expanse of forests in the Eastern Arc and not just the submontane and montane forests.

\section{Dry country elements}

Several typical arid habitat taxa that occur in the Mkomazi-Tsavo area (e.g. Lack 1994) were recorded in the Bombo Valley sites we surveyed. Dry country species included Pygmy Batis Batis perkeo, Hunter's Sunbird Nectarinia hunteri, Redheaded Weaver Anaplectes rubriceps, Yellow-spotted Petronia Petronia pyrgita, Abyssinian White-eye Zosterops abyssinicus, African Penduline Tit Anthoscopus caroli and White-crested Helmet-shrike Prionops plumatus (Cordeiro and Githiru in press). Presence of these arid habitat elements in the Bombo Valley can be attributed to Acacia wooded grasslands which form a link with the MkomaziTsavo vegetational belt. Our records of these species were mainly from Acacia woodlands or in the ecotone between this habitat and the Brachylaena woodland.

\section{Globally threatened and near-threatened species not recorded in this survey}

Some globally threatened (T), near-threatened (NT) (Collar et al. 1994) and restricted-range (R-R) (Stattersfield et al. 1998) species known from other lowland forest patches in the East Usambaras (Stuart 1989, CTRP 1994, Anderson et al. 1997, Evans 1997a,b) went unrecorded at all three sites: Sokoke Scops Owl Otus ireneae (T), East Coast Akalat Sheppardia gunningi (T), Swynnerton's Robin Swynnertonia swynnertoni (T) and Kenrick's Starling Poeoptera kenricki (R-R). The apparent absence of the akalat (habitat of Swynnerton's Forest Robin not present in study sites) and starling may be real as an intense effort was made to locate these species through mist-netting and audio-visual observations, including playback. However, the possibility that they may have been overlooked cannot be ruled out, especially in the case of the elusive akalat. The owl was recently discovered in the East Usambara lowland forests (CTRP 1994, Evans 1997a,b) and due to its presence in the Brachylaena-Cynometra woodland in nearby Arabuko-Sokoke Forest, Kenya (Virani 1994, 1996), it may have been expected to occur in the Bombo Valley. All the methods employed to locate the akalat and starling were also used to search for this owl, but to no avail. As it has only been found below $400 \mathrm{~m}$ in the Usambaras and since most parts of the reserves were at or above $400 \mathrm{~m}$, it is possible that the conditions for this species were not ideal. Another plausible theory for the lack of any records is that it may occur at very low densities, compared with other sites in the Usambara lowlands (Evans 1997b) and thus could have been overlooked. 


\section{Discussion}

Habitat degradation and conservation in the East Usambaras

Prior to the 1990s, forest cover was being rapidly lost to several damaging human-related activities (see Hamilton and Bensted-Smith 1989). However, since 1993, EUCFP has made great strides to afford protection to the forests in this range. Current forest area under the jurisdiction of EUCFP is 45,137.7 ha, a figure that includes proposed forest reserves and some woodland areas (Johansson and Sandy 1996). This is more than twice the amount (i.e. 21,900 ha) in 1993 (Hyytiäinen 1995) and mainly results from EUCFP's efforts to enlarge existing forest reserves, incorporate unprotected forests into their programme and link fragmented forests by establishing forest corridors. Johansson and Sandy (1996) state that $75 \%$ of the total forest area is in, or will receive, forest reserve status in the very near future whereas about $95 \%$ of the well-stocked forests are already in forest reserves. With regard to lowland forests which amount to 29,497 ha, about $81 \%$ have, or will receive in the near future, forest reserve status, and about $98 \%$ of the more intact forest is already in forest reserves (Johansson and Sandy 1996). Bombo East PFRs are two examples of EUCFP's recent incorporation of a fairly large area of Brachylaena woodland and several small lowland forest patches into their forest reserve network.

The achievement of the EUCFP is remarkable and exemplifies an outstanding model for other forestry bodies to follow. However, although many humanrelated conflicts were sufficiently managed through the planning stages of the proposed reserves, the degradation of surrounding habitats not included in the reserve boundaries is a major concern. Regulating the use of buffer zones, planting woodlots for fuelwood supplementation, restricting and controlling grazing, enforcing proper fire control measures (e.g. by establishing fire strips around farms) and especially enhancing overall awareness of the local people will go a long way in ensuring that these habitats are well managed and conserved.

\section{Comparison between study areas and East Usambara lowland forest avifauna}

Not including possible altitude migrants from montane areas and some Afrotropical migrants, at least 15 species that are known to occur at several forested sites in the East Usambara lowlands (Stuart 1989, CTRP 1994, Evans 1997a) went unrecorded during this investigation. These include: Eastern Bronze-naped Pigeon Columba delegorguei, Sokoke Scops Owl, Usambara Eagle-Owl Bubo vosseleri, Eastern Green Tinkerbird Pogoniulus simplex, Green Barbet Stactolaema olivacea, Little Greenbul Andropadus virens, Yellow-streaked Greenbul Phyllastrephus flavostriatus, Pale-breasted Illadopsis Illadopsis rufipennis, Swynnerton's Robin, East Coast Akalat, Kretschmer's Longbill Macrosphenus kretschmeri, Southern Hyliota Hyliota australis, Square-tailed Drongo Dicrurus ludwigii, Green-headed Oriole Oriolus chlorocephalus, Uluguru Violet-backed Sunbird Anthreptes neglectus. For many, the possibility that they were overlooked cannot be ruled out as several of them occur at low densities (e.g. Sokoke Scops Owl) or are very elusive (e.g. Southern Hyliota Hyliota australis). Furthermore, for some species (e.g. Swynnerton's Robin), unsuitable habitat may explain their absence. However, for the more conspicuous and vocal species like the Green Barbet, Yellow-streaked Greenbul, 
Square-tailed Drongo and Green-headed Oriole, the apparent absences are difficult to understand, especially in the mixed dry forest in Bombo East I PFR. It is possible that the small sizes of mixed dry forest patches, together with the lack of large, mature trees, which are characteristic of lowland forests where these species are known to occur, may explain their absence in our study sites. However, the scant ecological information available on these birds makes any observed patterns difficult to interpret with confidence.

With regard to differences in the avifauna between the mixed dry forest (Bombo East I PFR) and the Brachylaena woodland, although several species overlap (see Table 3), the absence of some more typical forest species in the latter habitat is of interest. Forest birds such as the Black-headed Apalis Apalis melanocephala, Tiny Greenbul Phyllastrephus debilis, Forest Batis Batis mixta, Olive Sunbird Nectarinia olivacea and Dark-backed Weaver Ploceus bicolor, which were not recorded in the drier Brachylaena woodland, indicate the overall impoverishment of this habitat compared with the mixed dry forest. It therefore appears that although these woodlands harbour some important bird species, their overall conservation status for the protection of birds, as currently understood, is not as high as that for Bombo East I PFR. Bombo East I PFR, with at least 65 species somewhat dependent on the mixed dry forest (Table 3 ) and a further 78 that inhabit the Acacia woodland, thickets and cultivation (N.J.C. and M.G. unpubl.), clearly maintains a high diversity of species. Nevertheless, in comparison with other lowland forests in the East Usambaras, where up to six globally threatened, three near-threatened and three restricted-range bird species occur, all three sites do not rank very high. Of importance, however, is the presence of some bird species of conservation concern together with the possibility that at least one site (Bombo East I PFR) serves as a cold season refuge for montane elements.

The landscape mosaic of all three reserves is made up of several types of contiguous habitats: mixed dry forest, Brachylaena woodland, Acacia wooded grassland. This mosaic was more prevalent in Bombo East I PFR than in the other two sites, and together with a larger area of mixed dry forest, could account for the higher bird diversity (in species richness and abundance, see results section). Bombo West FR was dominated by Brachylaena and only very small mixed dry forest patches were located on three hills. This woodland habitat was more uniform than the more stratified mixed dry forest which may be another reason that explains the reduced bird diversity in this reserve.

\section{Animals other than birds}

Although our coverage of mammals and other animal groups was not thorough, we obtained several records of conservation interest. The presence of the Tree Hyrax Dendrohyrax vallidus, Zanzibar Dwarf Galago Galagoides zanzibaricus, Zanj Elephant Shrew Rhynchocyon petersi, Lesser Pouched Rat Beamys hindei and a possible endemic snake (Prosymna sp. cf. Broadley 1995) raises the overall conservation value of the mixed dry forest and Brachylaena woodlands in this area.

\section{Recommendations for further fieldwork}

Given that a number species of birds and mammals of conservation concern, and one possible endemic reptile, were found in these study areas, the poten- 
tial for further discoveries is high. The following recommendations are therefore presented (see also CTRP 1994) to highlight these study sites and the Brachylaena woodland as important areas for future conservation and research efforts:

1. The avifauna of the mixed dry forest and Brachylaena woodland should be studied during all seasons to facilitate a more rounded view of the dynamics of this community. In addition, determining whether or not Bombo East I PFR and other sites could serve as cold season refugia for montane elements is of great concern given the overall evolutionary and conservation significance of this phenomenon. Furthermore, as two globally threatened birds (Sokoke Scops Owl, Sokoke Pipit Anthus sokokensis) inhabit comparable Cynometra-Brachylaena woodland in Kenya, their presence in the study areas is still very likely if they occur at very low densities. Due to this, we feel that the priority of surveying the Brachylaena woodlands north of the Bombo Valley, many patches of which are being degraded at high rates by wood-carving and charcoal industries, is very high. Further populations of this owl and other threatened bird and mammal species could be discovered. With regard to mammals, the occurrence of Ader's Duiker Cephalophus adersi, Golden-rumped Elephant Shrew Rhynchocyon chrysopygus and Sokoke Dog Mongoose Bdeogale omnivora in some of the woodland patches near the Kenya-Tanzania border is highly probable given their habitat requirements and proximity to the Kenyan coastal forests.

2. Ecological studies of key bird and mammal species, such as those of conservation importance, are of great necessity if we plan to create efficient conservation strategies for the species' future survival. What habitats they use, for what needs and at what times are also important ecological questions that can be addressed for model species or species of conservation concern in this system.

The accelerating destruction of the Brachylaena woodlands by the charcoal industry could be curbed by modelling schemes after EUCFP's programme in the Usambaras. These woodland tracts have no formal protection and therefore the overall conservation importance of this unique vegetation type merits immediate conservation attention. This could be done peacefully in the same manner as those forest reserves that were recently established in the northern extreme of the East Usambaras. Furthermore, setting aside key tracts, controlling the charcoal trade in the more damaged sites, and setting up wood-lots, may help ameliorate the current situation without causing grave harm to the livelihood of the people involved. However, because the demand for charcoal comes from nearby coastal towns, and Pemba and Zanzibar islands (from where it is also believed to be exported to parts of the Middle East), other alternatives need to be sought. Perhaps the study on the charcoal market by EUCFP (S. Johansson verbally 1998) will provide solutions to this problem. In particular, controlling the market and instituting the use of alternative energy sources (e.g. solar-powered cookers) could potentially reverse current trends. An alternative to charcoal, compressed sawdust from mills, is currently being explored by a Japanese Aid organization in Kilimanjaro Region (N.J.C. pers. obs.): if the quality is high and cost is relatively low, then it could become an important alternative to charcoal in urban areas. 
Given the serious threats to the poorly explored Brachylaena woodland patches north of the East Usambaras and their potential to house several endangered animals and plants, it is critical that further research and conservation strategies be focused on this habitat. Indeed, controlling the charcoal industry in the area will help decrease the advent of habitat degradation, which appeared to be quite high and a potential danger to local communities, the environment and the fauna and flora.

\section{Acknowledgements}

We are grateful to H. Nguli of COSTECH and the late M.I.L. Katigula of the East Usambara Catchment Project, Tanga Region, for permitting us to conduct research in the East Usambara lowlands. This project was sponsored by the Royal Society for the Protection of Birds, the U.K. partner of BirdLife, Fauna and Flora International (U.K.) and World Nature Association, all of whom N.J.C. is greatly indebted to. We also thank the village officials, villagers and forest officers (i.e. C. Ndakidemi, R. Muna, E. Msofe, J. Mtogolela and V. Mgonde) of Makorokoro, Maramba and Kilangangua. Staff in the Botanical Department of the National Museum, Kenya, are gratefully acknowledged for their assistance with plant identification. Further thanks to M. Schwartz for a GPS instrument given to N.J.C., S.K. Bearder for kindly identifying galago calls, and Neil Baker for providing rings and loaning other equipment. This project was encouraged and supported by N. E. and E. M. Baker, L. Bennun, N. D. Burgess, L. D. C. Fishpool, K. M. Howell, S. Johansson, M. I. L. Katigula, M. Mmasi, R. Sandy, J. Stevenson and A. Tye. The following read and commented on early versions of this paper: P. Buckley, N. D. Burgess, A. Entwistle, L. D. C. Fishpool, S. Johansson, M. I. L. Katigula, W. Stanley and P. Wood. Finally, we are indebted to L. Bennun, T. Brooks and an anonymous reviewer for providing numerous suggestions on the last draft.

\section{References}

AFIMP (1987) Results of a forest inventory of the East Usambara Mountains. Map Book. Helsinki: FINNIDA/IUCN.

Anderson, G. Q. A., Evans, T. D. and Watson, L. G. (1997) The Tanzanian race of Swynnerton's Robin Swynnertonia swynnertoni rodgersi. Bull. A.B.C. 4: 83-89.

Beentje, H. J. (1994) Kenya trees, shrubs and lianas. Nairobi: National Museums of Kenya.

Bennun, L. and Njoroge, P., eds. (1996) Birds to watch in East Africa: a preliminary red data list. Nairobi: National Museums of Kenya (Research reports of the Center for Biodiversity Ornithology, 23).

Britton, P. L., ed. (1980) Birds of East Africa, their status and distribution. Nairobi: East African Natural History Society.

Broadley, D. G. (1995) A new species of Prosymna Gray (Serpentes: Colubridae) from coastal forest in northeastern Tanzania. Arnoldia Zimbabwe 10: 29-32.

Broadley, D. G. and Howell, K. M. (in press) Reptiles. Pp. 191-209 in N. D. Burgess and G. P. Clarke, eds. Biodiversity and conservation of the coastal forests of eastern Africa. Gland and Cambridge, U.K.: IUCN.

Burgess, N. D. (in press) Global importance and patterns in the distribution of coastal forest species. Pp. 235-248 in N. D. Burgess and G. P. Clarke, eds. Biodiversity and conservation of the coastal forests of eastern Africa. Gland and Cambridge, U.K.: IUCN. 
Burgess, N. D., Dickinson, A. and Payne, N. P. (1993) Tanzanian Coastal Forests: new information on status and biological importance. Oryx 27: 169-173.

Burgess, N. D., Clarke, G. P. and Rodgers, W. A. (1998) Coastal forests of eastern Africa: status, endemism patterns and their potential causes. Biol. J. Linn. Soc. 64: 337-367.

Burgess, N. D., Kock, D., Cockle, A., FitzGibbon, C., Jenkins, P. and Honess, P. (in press) Mammals. Pp. 173-19o in N. D. Burgess, and G. P. Clarke, eds. Biodiversity and conservation of the coastal forests of eastern Africa. Gland and Cambridge, U.K.: IUCN.

Burgess, N. D. and Mlingwa, C. O. F. (in press) Evidence for altitudinal migration of forest birds between montane Eastern Arc and lowland forests in East Africa. Proceedings of the 1oth Pan-African Ornithological Congress, Accra, Ghana. Ostrich.

Clarke, G. P., Burgess, N. D., Rodgers, W. A. and Robertson, S. A. (in press) Vegetation Communities. Pp. 83-102 in N. D. Burgess and G. P. Clarke, eds. Biodiversity and conservation of the coastal forests of eastern Africa. Gland and Cambridge, U.K.: IUCN.

Collar, N. J., Crosby, M. J. and Stattersfield, A. J. (1994) Birds to watch 2: The world list of threatened birds. Cambridge, U.K.: BirdLife International(BirdLife Conservation Series 4).

Collar, N. J. and S. N. Stuart. (1985) Threatened birds of Africa and related Islands: the ICBP/ IUCN red data book. Cambridge, U.K.: International Council for Bird Preservation.

Cordeiro, N. J. (1998) A preliminary survey of the montane avifauna of Mt Nilo, East Usambaras, Tanzania. Scopus 20: 1-18.

Cordeiro, N. J. and Githiru, M. (1998) Avifauna of the Brachylaena woodlands in the East Usambara lowlands. Bull A.B.C. 5: 13-16.

Cordeiro, N. I. and Githiru, M. (in press) Birds of Mgambo Proposed Forest Reserve and other East Usambara lowland sites. Scopus.

Cordeiro, N. J. and Kiure, J. (1995) An investigation of the forest avifauna in the North Pare Mountains, Tanzania. Scopus 19: 9-26.

CTRP (Cambridge Tanzania Rainforest Project). (1994) A biological and human impact survey of the lowland forests, East Usambara Mountains, Tanzania. Cambridge,U.K.: BirdLife International (BirdLife Study Report 59).

Evans, T. D. (1997a) Records of birds from the forests of the East Usambara lowlands, Tanzania, August 1994-February 1995. Scopus 19: 92-108.

Evans, T. D. (1997b) Preliminary estimates of the population density of the Sokoke scops owl Otus ireneae Ripley in the East Usambara lowlands, Tanzania. Afr. J. Ecol. 35: 303311.

Evans, T. D. and Anderson, G. Q. A. (1993) Results of an ornithological survey in the Ukaguru and East Usambara mountains, Tanzania. Scopus 17: 40-47.

Evans, T. D., Watson, L. G., Hipkiss, A. J., Kiure, J., Timmins, R. J. and Perkin, A. W. (1994) New records of Sokoke Scops Owl Otus ireneae, Usambara Eagle Owl Bubo vosseleri and East Coast Akalat Sheppardia gunningi from Tanzania. Scopus 18: 40-47.

Hamilton, A. C. and Bensted-Smith, R. eds. (1989) Forest conservation in the East Usambara Mountains, Tanzania. Gland and Cambridge, U.K.: IUCN.

Hyytiäinen, K. (1995) Land use classification and mapping for the East Usambaras. Dar-esSalaam and Vantaa: Forestry and Beekeeping Division and Finnish Forest and Park Service and National Soil Service (East Usambara Catchment Forest Project Techn. Paper 12).

Johansson, S. G. and Sandy, R. (1996) Protected areas and public lands: land use in the East Usambaras. Dar-es-Salaam and Vantaa: Forestry and Beekeeping Division and Finnish Forest and Park Service and National Soil Service (East Usambara Catchment Forest Project Techn. Paper 28).

Karr, J. R. (1981) Surveying birds in the tropics. Stud. Avian Biol. 6: 548-553.

Lack, P. C. (1994) Three-streaked Tchagra Tchagra jamesi: a new record for Tanzania. Scopus 17: 140-141.

Lovett, J. C. and Pócs, T. (1993) Assessment of the condition of the catchment forest reserves, a 
botanical appraisal. Dar es Salaam: The Catchment Forestry Project-Forestry and Beekeeping Division, Ministry of Tourism, Natural Resources and Environment.

Lovett, J. C. and Wasser, S. K., eds. (1993) Biogeography and ecology of the rain forests of eastern Africa. Cambridge, U.K.: Cambridge University Press.

Mace, G. and Stuart, S. (1994) Draft IUCN Red List categories. Species 21/22: 13-24.

Mlingwa, C. O. F., Waiyaki, E. M., Bennun, L. A. and Burgess, N. D. (in press) Birds. Pp. 149-171 in N. D. Burgess and G. P. Clarke, eds. Biodiversity and conservation of the coastal forests of eastern Africa. Gland and Cambridge, U.K.: IUCN.

Moreau, R. E. (1935) A synecological study of Usambara, Tanganyika Territory, with particular reference to birds. J. Ecol. 23: 1-43.

Newmark, W. D. (1993) The role and design of wildlife corridors with examples from Tanzania. Ambio 22: 500-504.

Remsen, J. V. Jr. and Good, D. A. (1996) Misuse of data from mist-net captures to assess relative abundance in bird populations. Auk 113: 381-398.

Robertson, S. A. (1987) Preliminary floristic survey of Kaya forests of coastal Kenya. Nairobi: WWF.

Ruffo, C. K., Mwasha, I. V. and Mmari, C. (1989) The use of medicinal plants in the East Usambaras. Pp. 195-206 in A. C. Hamilton, and R. Bensted-Smith, eds. Forest conservation in the East Usambara Mountains, Tanzania. Gland and Cambridge, U.K.: IUCN.

Schmidt, P. R. (1989) Early exploitation and settlement in the Usambara Mountains. Pp. 75-78 in A. C. Hamilton, and R. Bensted-Smith, eds. Forest conservation in the East Usambara Mountains, Tanzania. Gland and Cambridge, U.K.: IUCN.

Sclater, W. L. and Moreau, R. E. (1932-1933) Taxonomic field notes on some birds of north-eastern Tanganyika Territory. Ibis (13)2: 487-522, 656-683; 3: 1-33, 187-219, 399440.

Seddon, N., Ekstrom, J. M. M., Capper, D. R., Isherwood, I. S., Muna, R., Pople, R. G., Tarimo, E. and Timothy, J. (1999) Notes on the ecology and conservation status of key bird species in Nilo and Nguu North Forest Reserves, Tanzania. Bird Conserv. Internatn. 9: 9-28.

Sheil, D. (1992) Tanzanian Coastal Forests: unique, threatened and overlooked. Oryx 26: 107-114.

SMD (Survey and Mapping Division) (1991) Hemagoma: sheet 110/3. Government of the United Kingdom (Ordnance Survey) for the United Republic of Tanzania.

Stattersfield, A. J., Crosby, M. J., Long, A. J. and Wege, D. C. (1998) Endemic bird areas of the world: priorities for biodiversity and conservation. Cambridge, U.K.: BirdLife International (BirdLife Conservation Series 7).

Stuart, S. N. (1983) Biogeographical and ecological aspects of forest bird communities in Eastern Africa. Ph.D. thesis, University of Cambridge.

Stuart, S. N. (1989) The forest bird fauna of the East Usambara Mountains. Pp. 357-361 in A. C. Hamilton, and R. Bensted-Smith, eds. Forest conservation in the East Usambara Mountains, Tanzania. Gland and Cambridge, U.K.: IUCN.

Svendsen, J. O., Hansen, L. A., Fjeldså, J., Rahner, M. C., Pedersen, L. B., Kisbye, H., Edvardsen, E, and Kiure, J. (1995) Section 5. Ornithology: Appendix 5. In J. O. Svendsen and L. A. Hansen, eds. Report on the Uluguru Biodiversity Survey 1993. Sandy, U.K.: The Royal Society for the Protection of Birds, Danish Centre for Tropical Biodiversity and Tanzania Forestry Research Institute.

Tye, A. (1993) Forest and bird conservation in the East Usambara Mountains, north-east Tanzania. In R. T. Wilson, ed. Birds and the African environment: proceedings of the eighth Pan-African Ornithological Congress. Ann. Mus. Royal Afr. Centr. (Zool.) 268: 287292.

Virani, M. Z. A. (1994) Ecology of the endangered Sokoke Scops owl (Otus ireneae). M.Sc. thesis, University of Leicester, U.K. 
Virani, M. (1996) The Sokoke Scops Owl Project: Who gives a hoot? Swara January/February: $24-27$.

Zimmerman, D. A., Turner, D. and Pearson, D. T. (1996) Birds of Kenya and northern Tanzania. South Africa: Russel Friedman.

NORBERT J. CORDEIRO

Department of Biological Sciences (M/C o66), University of Illinois at Chicago, 845 West Taylor Street, Chicago, IL 60607-7060, U.S.A. E-mail: ncorde1@uic.edu

MWANGI GITHIRU

Department of Ornithology, National Museums of Kenya, PO Box 40658, Nairobi, Kenya. E-mail: kbirds@africaonline.co.ke 